Original Article

\title{
EARLY FLORAL RESOURCES FOR URBAN BEES FROM ORNAMENTAL SHRUBS RIBES AUREUM, RIBES SANGUINEUM AND STAPHYLEA PINNATA
}

\author{
Marzena Masierowska* \\ Department of Botany and Plant Physiology, University of Life Sciences in Lublin, \\ Poland \\ *corresponding author: mIm25@up.lublin.pl \\ Received: 02 March 2020; accepted: 21 July 2020
}

Acstract

This research aims to assess ornamental shrubs Ribes aureum, $R$. sanguineum and Staphylea pinnata as an early food source for urban bees. In a two-year study, the abundance and flowering pattern, nectar and pollen production, and spectrum of urban insect visitors were investigated in Lublin, SE Poland. The apiarian value of $S$. pinnata was studied for the first time. The studied species exhibited abundant and extended flowering, skewed inflorescence flowering pattern, and persistent flowers and inflorescences. They bloomed from late March to late May and could be considered as valuable early foraging resources for urban bees, despite the substantial differences between the species. The highest mean sugar yield and pollen yield · plant $^{-1}$ (92.9 g and $44.0 \mathrm{~g}$, respectively) was estimated for $S$. pinnata whereas the lowest ones were found in $R$. sanguineum (4.3 g and $1.8 \mathrm{~g}$, respectively). Hymenopterans were the principal flower visitors in the studied species accounting for more than $79 \%$ of all visits.

Keywords: bee pasture, flowering, nectar, pollen, spring-flowering plants

\section{INTRODUCTION}

Bees are principal contributors to pollination services in both the natural and anthropogenic habitats (Klein et al., 2007). Insect pollination is a key factor in seed and fruit yield, ensuring the reproduction of plant species and providing food for humans and wildlife. In the past decade, one of the fastest emerging traditions in cities has been urban agriculture, including beekeeping (Peters, 2012; Marìn et al., 2019). Urban agriculture provides such multiple benefits as food production, relaxation and the saving of cultural heritage (Marìn et al., 2019). However, such activities require proper "bee-friendly" management of urban areas, including the selection and use of plants for example valuable nectar and pollen resources. Urban areas contain patches of unused land including road verges or ruderal areas and such amenity areas as parks, lawns and roofs. This is a potential to alter the management of this land and to create an attractive flower-rich landscape thus increasing food pasture for insect pollinators, including bees (Matteson, Grace \& Minor, 2013; Larcher et al. 2017). Ornamental plants can provide insects with considerable amounts of nectar and pollen and contribute to the diversity of food resources within cities (Garbuzov \& Ratnieks, 2014; Masierowska et al., 2018; Jachuła et al., 2019).

The warming Urban Heat Island effect, increased water stress and pollution contribute to cities' specific environmental conditions (Pickett et al., 2011) and may affect plant-pollinators relations. Spring-flowering plants tend to advance their blooming in urban habitats (Neil \& Wu, 2006). Honeybees, queen bumblebees and solitary bees are active early in the year in cities (Hicks et al., 2016). Spring is a period of high nutritional demand for spring-emerging bees, which lose a lot of weight during over-wintering in response to warm winters (Fründ, Zieger, \& Tscharntke, 2013). Thus, an adequate quality and quantity of early floral resources is vital for their development and activity. Spring forage limitation is currently considered as a possible driver of the negative impact of urbanization on bees (Harrison \& Winfree, 2015). Early in the 
year (April-May), nectar and pollen are usually provided by native perennial weeds (Denisow, 2011), which are problematic from the aesthetic point of view. Thus, incorporating ornamental trees, shrubs or flowers into green space landscaping can enhance both the availability of early season resources to urban bees and the aesthetic value of the urban landscape.

The attractiveness of plants to insects depends on the traits of flower morphology and colour, pollen and nectar quality (Garbuzov \& Ratnieks, 2014), flowering pattern and floral-display size (Thompson, 2001) and these should be considered when selecting plants for bee pasture. The aim of this study was to evaluate three shrubs Ribes aureum Pursh., Ribes sanquineum Pursh., and Staphylea pinnata L. as early food resources for urban bees and more specifically to determine (i) the abundance and flowering pattern, (ii) the nectar and pollen production, and (iii) the spectrum of urban insect visitors, in particular bees. The Ribes species are the drought-tolerant shrubs with high aesthetic value (Borowski et al., 2016; Muras, 2017). Staphylea pinnata is a native species with original flowers and fruits, and in the past plants of the species were transferred from natural stands and planted in gardens. Moreover, this species is light and soil tolerant (Dolatowski \& Seneta, 2020).

Since studies on the apiarian value of ornamental Ribes species in SE Poland in the 1990s (Masierowska, 1993; 1995), the attractiveness of these shrubs to urban pollinators has not been studied despite common changes in the urban environment, including the UHI effect, altered precipitation or land-use change, noted also in the city studied here (Rysiak \& Czarnecka, 2018). The attractiveness of $S$. pinnata has never been evaluated, although it is listed as a melliferous plant in Poland (Lipiński, 2010).

\section{MATERIAL AND METHODS}

\section{Study site and study species}

The study was conducted in 2014-2015 in the UMCS Botanical Garden, Lublin, SE Poland $\left(51^{\circ} 16^{\prime} \mathrm{N}, 22^{\circ} 30^{\prime} \mathrm{E} ; 200 \mathrm{~m}\right.$ a.s.l.). The local climate is characterized by an average annual air temperature of $7.9^{\circ} \mathrm{C}$ and average annual precipitation of $556 \mathrm{~mm}$. The average length of the growing season is 209 days (Rysiak \& Czarnecka, 2018).

Ribes aureum, $R$. sanguineum (Grossulariaceae), and Staphylea pinnata (Staphyleaceae) are deciduous shrubs and have multi-flowered inflorescences - racemes (Ribes species) or thyrses (S. pinnata). The flowers of $R$. aureum and $R$. sanguineum have a tubular hypanthium consisting of five fused sepals with spreading lobes and five shorter erect petals. The flowers have five stamens and one pistil with a two-lobed stigma. $R$. aureum flowers are golden yellow but turn reddish after fertilization. The sepals of $R$. sanguineum are pink/red, whereas the petals are white which turn rose-red with age (Knuth, 1908). The flowers of S. pinnata have a short-campanulate hypanthium consisting of five white sepals with reddish tips and five white erect petals. They have five stamens and one to two pistils (Knuth, 1908). In both Ribes species, nectar is produced by astructural receptacular nectaries (Masierowska, 1993), whereas in S. pinnata it is secreted by a nectary disc covering the receptacle (Knuth, 1908).

The studied Ribes species are native to North America. In Poland, they have been cultivated since the early 1800s (Hereźniak, 1992). S. pinnata is distributed in some parts of central and southern Europe as well as in Asia Minor. In Poland, this is a rare and legally protected plant, primarily found in forests and coppices (Rutkowski, 2006).

The experimental plants were exposed to sun grown on loess-originated soil. Four shrubs per species were used in this study.

\section{Flowering and insect visitors to flowers}

The onset and termination of blooming were recorded. The abundance of flowering (number of flowers ' shrub ${ }^{-1}$ ) was estimated by multiplying the mean number of flowers ' inflorescence-1 ( $n=20$ inflorescences recorded per plant), the number of inflorescences ' shoot $^{-1}$ and thenumber of shoots ' shrub ${ }^{-1}$. The flower and inflorescence lifespan was established as a period between 
a flower bud opening and perianth closing, and between the first flower opening and the last flower closing in an inflorescence, respectively. The number of randomly chosen flowers and inflorescences is shown in Tab. 1. For the examination of the inflorescence flowering pattern in 2015 , four inflorescences were randomly chosen on each studied plant and marked prior to the opening of the first flowers. On the consecutive days of blooming, the number of newly opened flowers in each inflorescence was counted until blooming terminated. The flowering pattern was expressed as the percentage of newly opened flowers on the successive flowering days in relation to the total number of flowers formed in the inflorescence.

In 2014 and 2015, during the peak blooming of the plants, a spectrum and abundance of bee visitors were noted. Five-minute observations were made three times every hour from 9.00 to 17.00 (GMT + 2 hrs) for two to three consecutive days in sunny and non-windy weather. The observations were performed in four marked areas on a shrub canopy, each sized $0.12 \mathrm{~m}^{2}$.

\section{Nectar and pollen production}

Nectar production was studied using the Jabłoński pipette method (2002). Prior to sample collection, flower buds in the middle part of randomly selected inflorescences were marked and then whole inflorescences were isolated with tulle isolators to exclude insect visits. Accumulated nectar was sampled from the marked Ribes species flowers after their petals had changed color and anthers had run out of pollen. In S. pinnata, nectar samples were collected when the marked flowers still presented pollen. A preliminary examination revealed that the highest amount of sugars secreted in nectar was present at these floral stages. A single sample contained nectar from five to fifteen flowers of different inflorescences. The total number of nectar samples collected in 2014 and 2015 was fifty-three and forty-one, respectively. The

Flowering period and abundance, lifespan of flowers and inflorescences in the studied species throughout the years of study

\begin{tabular}{|c|c|c|c|c|c|c|}
\hline \multirow{2}{*}{ Species } & \multirow{2}{*}{ Year } & \multirow{2}{*}{$\begin{array}{c}\text { Flowering period } \\
\text { (days) }\end{array}$} & \multicolumn{2}{|c|}{ No. of flowers:* } & \multicolumn{2}{|c|}{ Lifespan (days) of:* } \\
\hline & & & inflorescence $^{-1}$ & shrub $^{-1}$ (thous.) & flower & inflorescence \\
\hline $\begin{array}{l}\text { Ribes } \\
\text { aureum }\end{array}$ & $\begin{array}{l}2014 \\
2015 \\
\text { mean }\end{array}$ & $\begin{array}{c}17 \text { April-9 May (23) } \\
25 \text { April-12 May (28) } \\
\text { (26) }\end{array}$ & $\begin{array}{l}7.6 \pm 1.8(20) \\
8.0 \pm 1.7(20) \\
7.8^{\mathrm{C}} \pm 1.8(40)\end{array}$ & $\begin{array}{c}8.7 \pm 0.9(4) \\
19.5 \pm 2.3(4) \\
14.1^{\mathrm{AB}} \pm 6.0(8)\end{array}$ & $\begin{array}{l}7.2 \pm 1.2(20) \\
5.4 \pm 0.7(20) \\
6.3^{\mathrm{B}} \pm 1.3(40)\end{array}$ & $\begin{array}{c}15.7 \pm 3.8(15) \\
10.1 \pm 1.3(18) \\
12.6^{\mathrm{B}} \pm 3.9(33)\end{array}$ \\
\hline $\begin{array}{c}\text { Ribes } \\
\text { sanguineum }\end{array}$ & $\begin{array}{l}2014 \\
2015 \\
\text { mean }\end{array}$ & $\begin{array}{c}25 \text { March-14 April (20) } \\
11 \text { April-10 May (30) } \\
\text { (25) }\end{array}$ & $\begin{array}{c}19.1 \pm 4.0(20) \\
18.5 \pm 4.0(20) \\
18.8^{\mathrm{B}} \pm 4.4(40)\end{array}$ & $\begin{array}{l}5.2 \pm 2.5(4) \\
5.6 \pm 1.7(4) \\
5.4^{\mathrm{B}} \pm 1.9(8)\end{array}$ & $\begin{array}{l}8.6 \pm 1.2(20) \\
6.0 \pm 0.7(20) \\
7.3^{A} \pm 1.6(40)\end{array}$ & $\begin{array}{c}19.3 \pm 4.4(18) \\
14.4 \pm 1.8(18) \\
16.9^{A} \pm 4.1(36)\end{array}$ \\
\hline $\begin{array}{l}\text { Staphylea } \\
\text { pinnata }\end{array}$ & $\begin{array}{l}2014 \\
2015 \\
\text { mean }\end{array}$ & $\begin{array}{l}23 \text { April-20 May (28) } \\
28 \text { April-26 May (29) } \\
\text { (29) }\end{array}$ & $\begin{array}{c}30.5 \pm 8.0(20) \\
40.0 \pm 19.3(20) \\
35.2^{A} \pm 15.4(40)\end{array}$ & $\begin{array}{l}18.5 \pm 9.7(4) \\
92.9 \pm 2.0(4) \\
55.7^{A} \pm 4.2(8)\end{array}$ & $\begin{array}{l}7.5 \pm 1.5(20) \\
6.8 \pm 2.4(20) \\
7.1^{\mathrm{AB}} \pm 2.1(40)\end{array}$ & $\begin{array}{c}- \\
19.0 \pm 3.4(20) \\
19.0^{A} \pm 3.4(20)\end{array}$ \\
\hline $\begin{array}{l}\text { Mean for } \\
\text { the year of } \\
\text { study }\end{array}$ & $\begin{array}{l}2014 \\
2015\end{array}$ & $\begin{array}{l}(24) \\
(29)\end{array}$ & $\begin{array}{l}19.1^{\mathrm{a}} \pm 10.7(60) \\
22.2^{\mathrm{a}} \pm 17.5(60)\end{array}$ & $\begin{array}{c}10.8^{a} \pm 7.9(24) \\
39.3^{a} \pm 41.4(24)\end{array}$ & $\begin{array}{l}7.7^{\mathrm{a}} \pm 1.4(60) \\
6.0^{\mathrm{b}} \pm 1.6(60)\end{array}$ & \\
\hline
\end{tabular}

*Data are means \pm SD (numbers in brackets indicate number of flowers, inflorescences and shrubs, respectively). Means in columns with the same letter do not differ significantly among species (capital letters) (Kruskall-Wallis ANOVA, $\mathrm{H}$ - test) and between years of study (small letters) (Kolmogorov-Smirnov test); $\mathrm{p}>0.05$. 
number of samples per each species is shown in Tab. 2. The nectar sugar concentration (\% w/w) was measured with the RL-4 refractometer (PZO, Warsaw Poland), and the nectar sugar amount . flower $^{-1}(\mathrm{mg})$ was calculated based on the nectar amount (mg) and nectar sugar concentration.

Pollen production was determined using the protocol of Warakomska (1972). Each year, six samples for each species were collected and eighteen samples in total. A single sample contained fifty mature stamens, which were placed on previously tarred watch glasses and dried in a SUP-65G dryer (Wamed, Poland) at $30^{\circ} \mathrm{C}$ for several days. Pollen was rinsed from open anthers using $70 \%$ ethanol. The pollen samples were then dried and weighed on a balance (WA 34 PRL T A14 MERA-KFM, Poland), which allowed the calculation of the mass of air-dried pollen. The results were expressed in $\mathrm{mg} \cdot$ flower $^{1}$.

Moreover, sugar and pollen yield · shrub-1 (g) offered to insects was estimated with the use of the number of flowers - shrub ${ }^{-1}$ already formed during a given growing season on four plants of each species and mean nectar sugar amount flower ${ }^{-1}$ and pollen amount $\cdot$ flower $^{-1}$. Each year, twelve samples of sugar and pollen yields calculated for four plants of the three studied species were used to analyse the between-year variation.

\section{Data analysis}

All analyses were performed using STATISTICA v.13 (StatSoft Poland, Cracow). Two-way ANOVA tested for differences in nectar amount, nectar sugar concentration, total sugar amount in the nectar · flower ${ }^{-1}$, nectar sugar yield $\cdot$ shrub $^{-1}$, pollen amount ' flowe $r^{-1}$, and pollen yield $\cdot$ shrub $^{-1}$ between the taxa and years of the study. The percentage values of the nectar sugar concentration were transformed by arcsines. When significant differences were found, the ANOVA was followed by the HSD Tukey test at $p=0.05$. Differences in the number of flowers . inflorescence ${ }^{-1}$, number of flowers ' shrub ${ }^{-1}$, and flower lifespan among the species were tested using the Kruskal-Wallis non-parametric ANOVA and $\mathrm{H}$-test. The Kolmogorov-Smirnov test was applied for seasonal differences in these characteristics.

Table 2.

Nectar and pollen production in flowers of the studied species throughout the years of study

\begin{tabular}{|c|c|c|c|c|c|}
\hline Species & Year & $\begin{array}{l}\text { Nectar amount } \\
\text { flower }^{-1}(\mathrm{mg})\end{array}$ & $\begin{array}{l}\text { Nectar sugar } \\
\text { concentration } \\
(\% \mathrm{w} / \mathrm{w})\end{array}$ & $\begin{array}{c}\text { Nectar sugar } \\
\text { amount } \cdot \text { flower }{ }^{1} \\
(\mathrm{mg})\end{array}$ & $\begin{array}{l}\text { Pollen amount } \\
\text { flower }^{-1} \text { (mg) }\end{array}$ \\
\hline $\begin{array}{l}\text { Ribes } \\
\text { aureum }\end{array}$ & $\begin{array}{l}2014 \\
2015 \\
\text { mean }\end{array}$ & $\begin{array}{l}5.3 \pm 1.8(22) \\
4.6 \pm 2.1(11) \\
5.0^{A} \pm 1.9(33)\end{array}$ & $\begin{array}{c}28.3 \pm 5.2(22) \\
31.7 \pm 9.1(11) \\
29.5^{A} \pm 6.8(33)\end{array}$ & $\begin{array}{c}1.5 \pm 0.6(22) \\
1.4 \pm 0.6(11) \\
1.5^{A} \pm 0.6(33)\end{array}$ & $\begin{array}{c}0.4 \pm 0.0(6) \\
0.4 \pm 0.1(6) \\
0.4^{\mathrm{B}} \pm 0.1(12)\end{array}$ \\
\hline $\begin{array}{c}\text { Ribes } \\
\text { sanguineum }\end{array}$ & $\begin{array}{l}2014 \\
2015 \\
\text { mean }\end{array}$ & $\begin{array}{l}4.4 \pm 1.5(10) \\
2.3 \pm 0.9(11) \\
3.2^{\mathrm{B}} \pm 1.5(21)\end{array}$ & $\begin{array}{l}38.5 \pm 4.5(10) \\
30.1 \pm 3.2(11) \\
34.1^{A} \pm 4.9(21)\end{array}$ & $\begin{array}{c}0.9 \pm 0.3(10) \\
0.7 \pm 0.3(11) \\
0.8^{8} \pm 0.3(21)\end{array}$ & $\begin{array}{c}0.4 \pm 0.1(6) \\
0.4 \pm 0.0(6) \\
0.4^{\mathrm{B}} \pm 0.0(12)\end{array}$ \\
\hline $\begin{array}{c}\text { Staphylea } \\
\text { pinnata }\end{array}$ & $\begin{array}{l}2014 \\
2015 \\
\text { mean }\end{array}$ & $\begin{array}{c}4.6 \pm 1.7(21) \\
5.6 \pm 2.5(19) \\
5.1^{A} \pm 2.2(40)\end{array}$ & $\begin{array}{c}35.4 \pm 11.4(21) \\
30.7 \pm 7.4(19) \\
33.2^{A} \pm 28.6(40)\end{array}$ & $\begin{array}{c}1.5 \pm 0.4(21) \\
1.7 \pm 0.8(19) \\
1.6^{\AA} \pm 0.6(40)\end{array}$ & $\begin{aligned} & 0.8 \pm 0.1(6) \\
& 0.8 \pm 0.1(6) \\
& 0.8^{A} \pm 0.1(12)\end{aligned}$ \\
\hline
\end{tabular}

Data are means \pm SD (numbers in brackets indicate number of collected samples). Untransformed data are presented. Means in columns with the same letter do not differ significantly among species (HSD Tukey's test, $\mathrm{p}>0.05$ ) 


\section{Ј. APPC. SOLI. VOL. 64 N NO. 2 2020}

\section{RESULTS}

\section{Flowering}

Detailed data of the seasonal flowering period and abundance are shown in Tab. 1. In the climatic conditions of Lublin, SE Poland, blooming of the studied species lasted from late March to late May. The time of blooming differed among the taxa and between the years of the study. The $R$. sanguineum shrubs were the first to bloom, whereas $S$. pinnata started last. $R$. aureum and $S$. pinnata bloomed up to four weeks. In $R$. sanguineum, the flowering period ranged from three weeks to one month. The blooming time depended on weather conditions during both the flowering period and the preceding period. Generally, the late winter and early spring in both growing seasons were very mild, but the daily mean temperatures of February and March 2014 were extremely high and exceeded the multiyear mean values by $4.1^{\circ} \mathrm{C}$ and $5^{\circ} \mathrm{C}$, respectively. This extremely warm weather accelerated the blooming process in the plants by five to fourteen days, compared to 2015 (Tab. 1).

The species significantly differed in both the mean number of flowers · inflorescence ${ }^{-1}\left(\mathrm{H}_{2,109}\right.$ $=86.18, \mathrm{p}<.001)$ and the mean number of flowers - shrub-1 $\left(\mathrm{H}_{2,24}=16.96, \mathrm{p}<.001\right)$. The highest number of flowers developed in the inflorescences of $S$. pinnata, whereas the lowest number (4-fold lower) was noted in $R$. aureum. A single $S$. pinnata shrub produced 4-fold and 10 -fold greater numbers of flowers than $R$.aureum and $R$. sanguineum, respectively. The number of flowers $\cdot$ inflorescence ${ }^{-1}$ did not differ significantly between the years of the study (Kolmogorov-Smirnov test; $d f=1, p>$.05). The number of flowers ' shrub ${ }^{-1}$ varied between the growing seasons although not statistically (Kolmogorov-Smirnov test; df = 1, p > .05). In 2015, the flowering abundance was higher than in 2014, in particular in S. pinnata whose plants produced 5 -fold higher numbers of flowers than in 2015 (Tab. 1) despite the similarly warm and wet weather in May 2014 and 2015.

The lifespan of the flowers and inflorescences differed significantly among the species $\left(\mathrm{H}_{2,120}\right.$ $=7.33, \mathrm{p}=.003$ and $\left.\mathrm{H}_{2,89}=29.08, \mathrm{p}<.001\right)$. The flowers and inflorescences of $S$. pinnata and $R$. sanguineum lived longer than those of

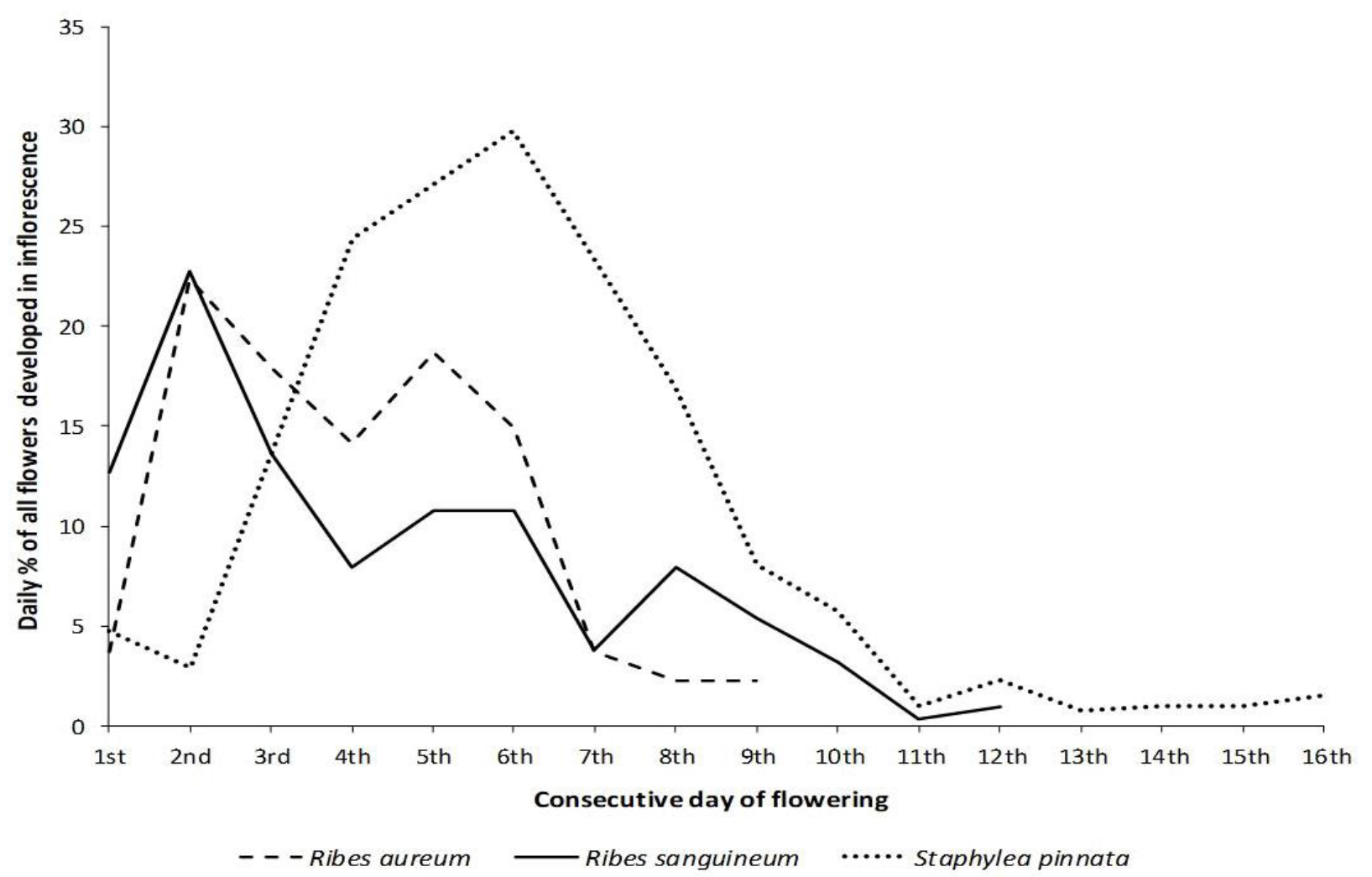

Fig. 1. Inflorescence flowering pattern in the studied species in 2015. Mean values are presented $(n=16$; $\mathrm{n}$ - number of inflorescences). 
R. aureum (Tab. 1). The seasonal differences in the flower persistence were significant (Kolmogorov-Smirnov test; $d f=1, p<.05)$. In 2014 the mean lifespan of a single flower was 1.7 days longer than that in 2015 (Tab. 1).

Blooming in the inflorescences started with a small number of flowers but peaked quickly between the second and sixth days after first flower opening with a few local maxima before a decline, leading to a skewed distribution (Fig. 1). During the peak in all the species, the daily portion of newly opened flowers exceeded $22 \%$ of all flowers developed in an inflorescence.

\section{Insect visitors}

The observations revealed the presence of honeybees, bumblebees, solitary bees, and dipterans. The proportion of insect groups visiting the flowers of the plant species in the years of the study is shown in Fig. 2. Hymenopterans accounted for more than $79 \%$ of all visits. Bumblebees were the principal visitors to $R$. sanguineum flowers, whereas honeybees dominated among insects visiting S. pinnata. Bumblebees were the most abundant flower visitors of $R$. aureum in 2014, whereas honeybees dominated in 2015 . The flowers of all the species were visited by a number of syrphid flies as well, and in particular S. pinnata lured these insects (21\% of the total number of insect visits in 2014).

Bees collected both nectar and pollen from the flowers but were more interested in nectar. The microscopic analysis of orange corbicular pollen loads of honeybees foraging on $S$. pinnata flowers confirmed the presence of numerous conspecific pollen grains (unpub. data).

\section{Nectar and pollen production}

The characteristics of nectar produced by the flowers of the studied species in the consecutive growing seasons (mean values and number of samples) are shown in Tab. 2. All the parameters of mean nectar amount, nectar sugar concentration and nectar sugar amount . flowe $r^{-1}$ found for the three species did not vary significantly between the years of the study $\left(F_{1,88}=0.12, p=.91 ; F_{1,88}=3.53, p=.06\right.$, and $F_{1,88}=1.37, p=.26$, respectively). However, the investigated species differed significantly in the mean nectar amount $\cdot$ flowe $^{-1}\left(F_{2,88}=14.13, p<\right.$ .01) and the mean nectar sugar amount $\cdot$ flower $^{-1}$ $\left(F_{2,88}=14.35, p<.01\right)$. S. pinnata appeared to be the best nectar producer. The mean amounts of nectar and nectar sugar secreted by its flower were similar to those found for $R$. aureum but

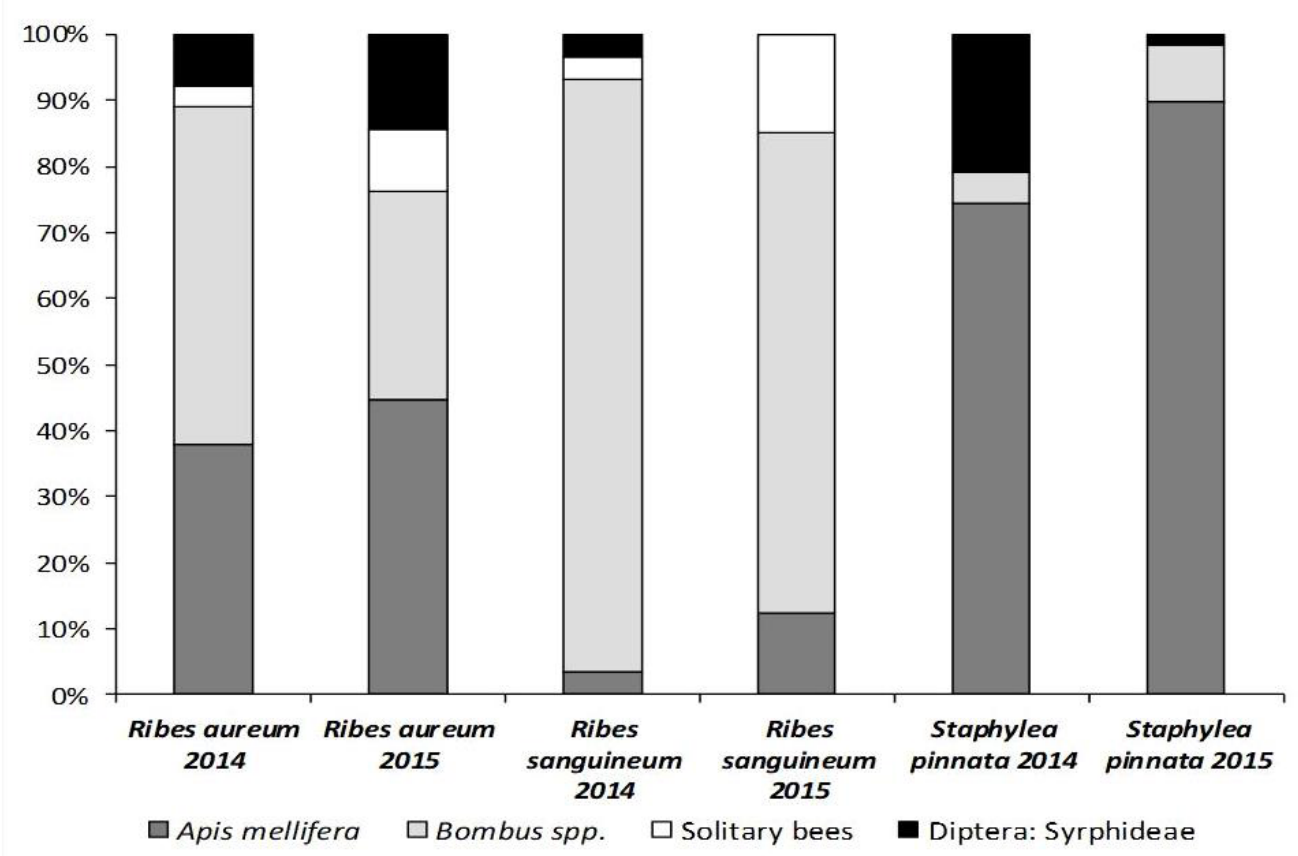

Fig. 2. Insect visits expressed as the percentage of total visits to the flowers of the studied species recorded in a particular study year and groups of flower visitors. 
respectively 1.6-fold and twice higher than values determined for $R$. sanguineum (Tab. 2). The estimated mean sugar nectar yield $\cdot$ plant $^{-1}$ in S. pinnata was up to 21.5 -fold higher than that calculated for the other species (Fig. 3). The sugar nectar concentration in all species was moderate (Tab. 2) and showed no species effect $\left(F_{2,88}=2.20, p=.12\right)$.

The mean pollen amount produced by a single flower differed significantly among the species $\left(F_{2,30}=202.61, p<0.01\right)$ but not between the years of the study $\left(F_{1,30}=2.13, p=.16\right)$ (Tab.2). Again, the highest amount of pollen was produced by $S$. pinnata flowers, while the values of $R$. aureum and $R$. sanguineum were twice as low. The estimated mean pollen yield - plant ${ }^{-1}$ in S. pinnata was 7.7-fold and 21-fold higher than those calculated for $R$. aureum and $R$. sanguineum, respectively (Fig. 3). The estimated sugar and pollen yields $\cdot$ plant $^{-1}$ were significantly higher in $2015\left(F_{1,18}=59.28, p<\right.$ .01 and $F_{1.18}=55.19, p<.01$, respectively) (Fig.3).

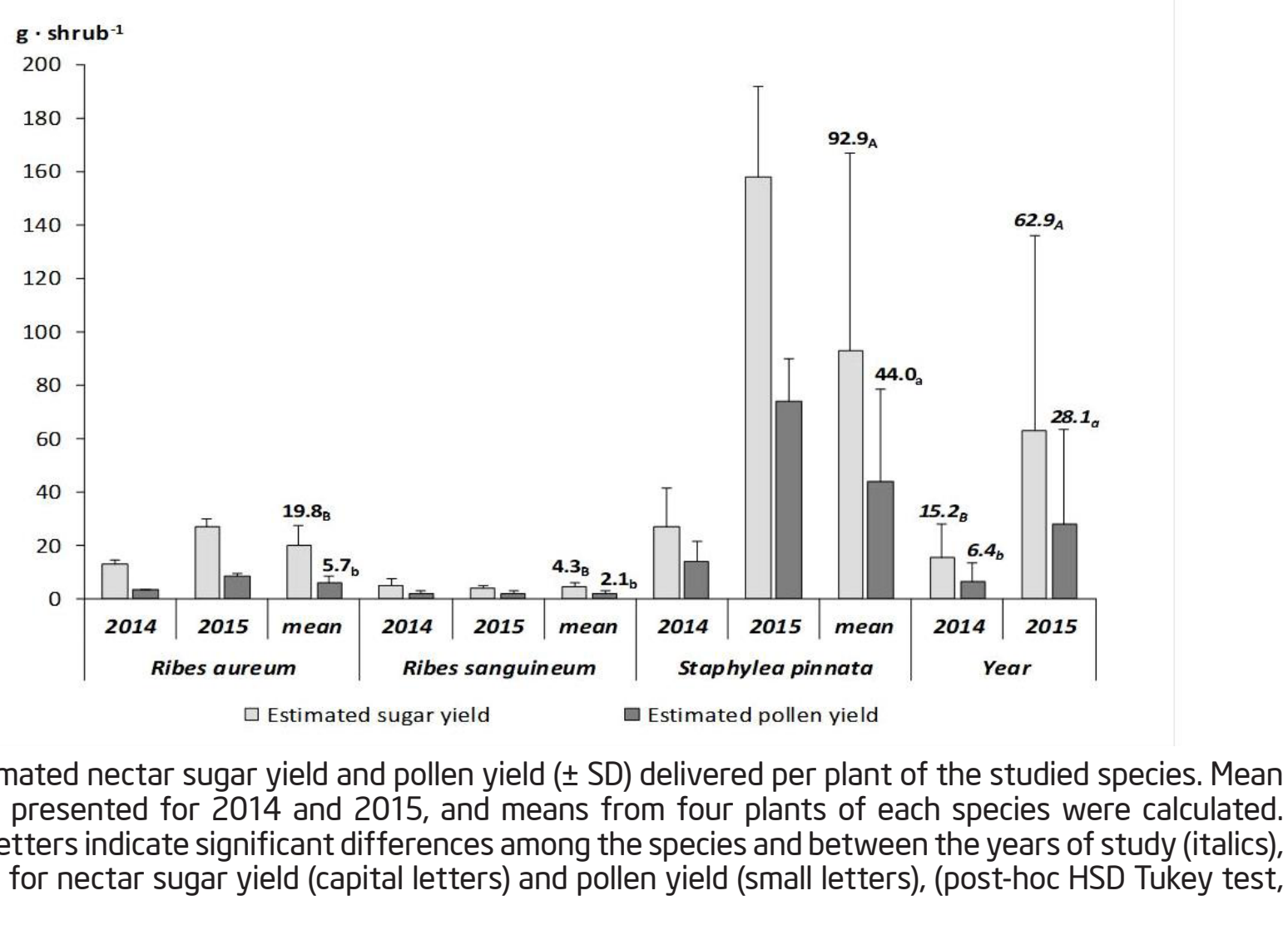

Fig. 3. Estimated nectar sugar yield and pollen yield $( \pm$ SD) delivered per plant of the studied species. Mean values are presented for 2014 and 2015, and means from four plants of each species were calculated. Different letters indicate significant differences among the species and between the years of study (italics), separately for nectar sugar yield (capital letters) and pollen yield (small letters), (post-hoc HSD Tukey test, $p<0.05)$.
Early spring is when both managed and wild bees have a high nutritional demand (Dick et al., 2015; Moquet et al., 2015), but also when there is often a shortage of nectar and pollen food (Lipiński, 2010; Denisow, 2011). However, thanks to the proper selection of plants, such urban flora as ornamental shrubs and trees (Somme et al., 2016) can provide bee species with a variety and continuity of floral resources and create good conditions for urban agriculture, including beekeeping. The results of this study expand the list of early-spring flowering shrubs that are useful for urban pollinators, including honeybees and bumblebees.

In all the plants observed in this study, the onset and length of blooming depended on weather conditions prevailing during the growing seasons and were probably affected by urban warming - a phenomenon recently confirmed for Lublin by Rysiak \& Czarnecka (2018). At high temperatures, the investigated shrubs, in particular $R$.sanguineum, advanced 
their blooming and had a shorter blooming period. In 1990s, when no urban warming was reported in the Lublin area, $R$. sanguineum and $R$. aureum flowered nearly two weeks later (mid-April-mid-May) (Masierowska, 1995) than in the present study. In Poland in natural stands, S. pinnata blooms in May and June (Rutkowski, 2006) while recently in Lublin in late April-May. Spring-blooming and insect-pollinated plants tend to be more sensitive to urbanization and usually advance their blooming, although many plant species do not show significant changes in flowering (see Neil \& Wu, 2006). A change in flowering time may lead to an asynchronous phenological mismatch between plants and their insect pollinators (Solga et al., 2014). Pollinators emerging after plant bloom might experience a decreased food supply, and plants that bloom before their pollinators are active may face pollination limitation (Fagan et al., 2014). A few experimental studies have found that both spring bees and the plants visited by them seem to advance their seasonal phenologies at similar rates and so avoid such a mismatch (Bartomeus et al., 2011; 2013). However, the phenological changes and their consequences are extremely species-specific (Solga et al., 2014) and need further investigations.

The studied species produced thousands of flowers gathered in inflorescences. In massflowering plants, the inflorescence rather than a single flower is a fundamental unit of pollinators' attraction, and the display of multiple flowers in the inflorescence increases plants' attractiveness to flower visitors (Harder et al., 2004). Despite the considerable differences in the number of flowers, the inflorescences of the studied species exhibit quite a similar pattern of flower presentation. They are characterized by continuous flower opening with a peak during the first days of blooming. By displaying numerous flowers from the beginning of bloom, the plant attracts inexperienced bees and encourages experienced ones to revisit (Makino \& Sakai, 2007). Thus, it obtains the services of faithful visitors that will continue to visit despite subsequent decreases in the rate of flower production (Thomson, 1985). Moreover, displaying many flowers might increase the likelihood of the plant being discovered by pollinators quickly (Makino \& Sakai, 2007).

The flowers in the studied species persisted for five to nine days on average. Their inflorescences lived up to 2.7 weeks. A prolonged flower and inflorescence lifespan appears to be of a great value to floral visitors, as it increases the size and length of floral display and thus extends the food supply (Willmer, 2011).

The studied species bloomed abundantly, in particular $S$. pinnata - the biggest shrub among the plants under study. The lowest number of flowers was produced by $R$. sanguineum, but their blooming abundance was relatively consistent throughout the years of the study. This matters when the aesthetic attractiveness of plants is considered before planting. In the other shrubs, there were more pronounced seasonal differences in the total number of flowers ' plant ${ }^{-1}$. Seasonal differences in flowering abundance have been reported for many ornamental species grown in urban habitats and mainly attributed to meteorological factors but also to species tendency to alternation of blooming (Denisow, 2002; Masierowska et al., 2018). This phenomenon is likely to be responsible for the major differences in the flowering abundance of $R$. aureum and S. pinnata in the consecutive years of the study, but a longer period of observation is necessary to prove this assumption.

Hymenopterans were the principal visitors to the flowers of the studied species. $R$. sanguineum attracted bumblebees, which is consistent with observations reported by Ostrowska (1981), and S. pinnata attracted mainly honeybees, as demonstrated by Lipiński (2010). However, Knuth (1908) reported that flies from the Syrphidae and Muscidae families were the only visitors to flowers of this species. In the present study, syrphid flies were never the dominant visitors to S. pinnata, although they accounted for $21 \%$ of all the insect visits in 2014. The proportions of bumblebees and honeybees visiting $R$. aureum flowers were similar but slightly fluctuated in the years of the study. In Poland, Ruszkowski (1998) listed $R$. aureum among indicator food 
plants for Bombus hortorum, B. ruderalis, and $B$. subterraneus, confirming its attractiveness to bumblebees. Knuth (1908) and Lipiński (2010) reported a minor interest of honeybees in $R$. aureumflowers and both authors attributed it to deeply concealed nectar. As shown by Lipiński (2010), honeybees are able to collect the nectar of this plant only through holes bitten in the tubular hypanthia by short-tongued bumblebees (secondary nectar robbing). In the present study, the $R$, aureum flowers produced a considerable amount of nectar filling the hypanthium tubes, which could be reached in a legitimate way by such bees with short mouthparts as $A$. mellifera. A similar mechanism was observed in honeybees visiting long-corolla Lonicera species (Jachuła et al., 2019). In the recent study, no nectar robbing on Ribes flowers was observed. However, bees more eagerly visited older $R$. aureum flowers than newly opened ones, probably due to the higher amounts of accumulated nectar.

Besides their high aesthetic value, both Ribes species and $S$. pinnata should be considered as additional nectar and pollen resources for bees. In the climatic conditions of SE Poland, the studied shrubs provide food from late March to late May. This may be important for bees with early activity in the urban environment, including honeybees, queen bumblebees, and solitary bees such as Andrena, Halictus, or Osmia (Hicks et al., 2016). The nectar-sugar quantities secreted in nectar per a single flower of $R$. aureum, $R$. sanguineum and $S$. pinnata were 1.5, 0.8 and $1.6 \mathrm{mg}$, respectively. Overall, most nectar characteristics for $R$. aureum and $R$. sanguineum were lower than the values previously reported in SE Poland (Masierowska, 1993; 1995). However, this is more than the nectar sugar amount $\cdot$ flower $^{-1}$ found for Salix (0.02-0.06 mg) (Koter, 1987) or Acer ( $0.46 \mathrm{mg}$ ) and Aesculus (0.16-0.28 mg) species (Somme et al., 2016), early spring/spring flowering shrubs and trees recommended for urban greenery planning. The surveyed shrubs provide moderately concentrated nectar although the values ranged from $15-50 \%$, which corroborates the results of previous studies on $R$. aureum and $R$. sanguineum (26-31\% on average) (Masierowska,
1993, 1995). Such nectar offers highly needed energy for such nectar consumers as flies and short- and long-tongued bees (Willmer, 2011). Indeed, both hymenopterans and dipterans were visitors to the Ribes and S. pinnataflowers in this study.

The amount of pollen available for insects from a single flower in all the species was small (0.4-0.8 mg) but similar to the values reported for the flowers of Aesculus (Warakomska, 1972) and Crataegus species (Szklanowska, 1992), which are commonly planted in cities. For both Ribes species, the pollen amount $\cdot$ flower $^{-1}$ was similar to the values reported in previous studies (Masierowska, 1993; 1995). For the first time, honeybees and bumblebees have been found to collect willingly $S$. pinnata pollen. Bees' pollen loads from $R$, aureum and $R$. sanguineum were described by Ostrowska (1981) and Hodges (1984).

The studied species produced a considerable number of flowers which resulted in a relatively high estimated sugar yield $\cdot$ plant $^{-1}$ in the range of 4.3-92.9 $\mathrm{g}$ and pollen yield . plant $^{-1}$ of 1.8-44.0 g (on average in both cases, $R$. sanguineum - S. pinnata, respectively). Due to the most abundant flowering and the high sugar nectar and pollen productivity of flowers, the estimated sugar and pollen yield . plant ${ }^{-1}$ in S. pinnata was much higher than the values calculated for the other taxa. Moreover, the sugar yield provided by this shrub was higher than that found for Lonicera tatarica and L. maackii (46.9-63.4 g · plant ${ }^{-1}$, respectively), which flower simultaneously with S. pinnata and are a good source of nectar sugars for urban bees in SE Poland (Jachuła et al., 2019). The estimated sugar yield and pollen yield in both Ribes species (4.3-19.8 g- and 1.8-6.1 g;, respectively) was in a range of values found previously in the Lublin area (4.3-34.7 $\mathrm{g}$ and 0.5-8.6 g, respectively) (Masierowska, unpub. data).

In conclusion, $R$, aureum, $R$, sanguineum, and S.pinnata shrubs can be considered as additional early floral food resources for urban bees. The studied species exhibit many such valuable features as abundant and extended flowering, skewed inflorescence flowering 
pattern, persistent flowers and inflorescences, and nectar and pollen reward ( $S$. pinnata in particular). When planted among urban greenery, they may help to achieve an ornamental effect, enrich bee pasture and improve bee nutrition in the early spring/spring period. Finally, a wider use of $R$. aureum, $R$. sanguineum, and $S$. pinnata in the urban landscape of Poland is recommended.

\section{ACKNOWLEDGMENTS.}

I thank Ernest Stawiarz Ph.D. for field assistance and analysis of pollen loads. This research was supported financially by the Ministry of Science and Higher Education of Poland as part of statutory activities of the Department of Botany and Plant Physiology (projects OKB/ DS/1 and 8), University of Life Sciences in Lublin

\section{REFERENCES}

Bartomeus, I., Ascher, J., Wagner, D., Danforth, B. N., Colla, S., Kornbluth S., Winfree, R. (2011). Climateassociated phenological advances in bee pollinators and bee-pollinated plants. Proceedings of the National Academy of Sciences of the United States of America, 108(51), 20645-2064.

Bartomeus, I., Park, M. G., Gibbs, J., Danforth, B. N., Lakso, A. N., Winfree, R. (2013). Biodiversity ensures plant-pollinator phenological synchrony against climate change. Ecology letters, 16(11), 1331-1338. https://doi.org/10.1111/ele.12170

Borowski. J., Fortuna-Antoszkiewicz, B., Łukaszkiewicz, J., Rosłon-Szeryńska, E., Sitarski, M., Suchocka, M., Wysocki, C. (2016). Standardy kształtowania zieleni Warszawy kwiecien2016. Retrieved February 8, 2020 from http://konsultacje. um.warszawa.pl/sites/konsultacje.um.warszawa.pl/ files/standardy_ksztaltowania_zieleni_warszawy_ kwiecien2016.pdf

Denisow, B. (2002). The blooming and melliferous value of tristilous flowers of Japanese quince (Chaenomeles japonica Lindl.). Journal of Apicultural Science, 46(2), 15-22.
Denisow, B. (2011). Pollen production of selected ruderal plant species in the Lublin area. Lublin: Univ Plant Sciences in Lublin Press.

Dicks, L. V., Baude, M., Roberts, S. P., Phillips, J., Green, M., Carvell, C. (2015). How much flower-rich habitat is enough for wild pollinators? Answering a key policy question with incomplete knowledge. Ecological Entomology, 40, 22-35. https://doi.org/10.1111/ een.12226

Dolatowski, J., \& Seneta, W. (2020). Dendrologia. $3^{\text {rd }}$ Edition. PWN, Warsaw.

Fagan, W. F., Bewick, S., Cantrell, S., Cosner, C., Varassin, I. G., Inouye, D. W. (2014). Phenologically explicit models for studying plant-pollinator interactions under climate change. Theoretical Ecology, 73), 289297. https://doi.org/10.1007/s12080-014-0218-8

Fründ, J., Zieger, S. L., \& Tscharntke, T. (2013). Response diversity of wild bees to overwintering temperatures. Oecologia, 173(4), 1639-1648. https://doi. org/10.1007/s00442-013-2729-1

Garbuzov, M., \& Ratnieks, F. L. (2014). Quantifying variation among garden plants in attractiveness to bees and other flower-visiting insects Functional Ecology, 28(2), 364-374. https://doi. org/10.1111/1365-2435.12178

Harder, L. D., Jordan, C. Y., Gross, W. E., \& Routley, M. B. (2004). Beyond floricentrism: the pollination function of inflorescences. Plant Species Biology, 19(3), 137-148.

Hereźniak, J. (1992). Amerykańskie drzewa i krzewy na ziemiach polskich. In Rośliny pochodzenia amerykanskiego zadomowione w Polsce. (pp. 97-450). Łódź: Łódzkie Towarzystwo Naukowe.

Hicks, D. M., Ouvrard, P., Baldock, K. C., Baude, M., Goddard, M. A., Kunin, W. E., ... Osgathorpe, L. M. (2016). Food for pollinators: quantifying the nectar and pollen resources of urban flower meadows. Plos ONE, 77(6), 1-37. https://doi.org/10.1371/journal. pone.0158117 
Hodges, D. (1984). The pollen loads of the honeybee. IBRA, London.

Jabłoński, B. (2002). Notes on the method to investigate nectar secretion rate in flowers. Journal of Apicultural Science, 46(2), 117-125.

Jachuła, J., Denisow, B., \& Strzałkowska-Abramek, M. (2019). Floral reward and insect visitors in six ornamental Lonicera species-Plants suitable for urban bee-friendly gardens. Urban Forestry \& Urban Greening, 44, 126390. https://doi.org/10.1016/j. ufug.2019.126390

Klein, A. M., Vaissiere, B. E., Cane, J. H., SteffanDewenter, I., Cunningham, S. A., Kremen, C., Tscharntke, T. (2007). Importance of pollinators in changing landscapes for world crops. Proceedings of the Royal Society B: Biological Sciences, 274(1608), 303-313. https://doi.org/10.1098/rspb.2006.3721

Knuth, P. (1908). Staphylea. Ribes. In Handbook of flower pollination. Vol. II, (pp. 245-246, 416-419). Oxford: Clarendon Press.

Koter, M. (1987). Nektarowanie i wydajność pyłkowa wybranych gatunków i mieszańców wierzb (Salix L.). Pszczelnicze Zeszyty Naukowe, 37, 131-154.

Larcher, F., Devecchi, M., Battisti, L., \& Vercelli, M. (2017). Urban horticulture and ecosystem services: challenges and opportunities for greening design and management. Italus Hortus 24 (1), 33-39. https://doi.org/10.26353/j.itahort/2017.1.3339

Lipiński, M. (2010). Pożytki pszczele, zapylanie i miododajność roślin. $4^{\text {th }}$ edn., PWRiL Warszawa and Sądecki Bartnik Press, Stróże.

Makino, T. T., \& Sakai, S. (2007). Experience changes pollinator responses to floral display size: from sizebased to reward-based foraging. Functional Ecology, 27(5), 854-863. https://doi.org/10.1111/j.13652435.2007.01293.x

Marín, L., Martínez-Sánchez, M. E., Sagot, P., Navarrete, D., Morales, H. (2020). Floral visitors in urban gardens and natural areas: Diversity and interaction networks in a neotropical urban landscape. Basic and
Applied Ecology, 43, 3-15. https://doi.org/10.1016/j. baae.2019.10.003

Masierowska, M., Stawiarz, E., \& Rozwałka, R. (2018). Perennial ground cover plants as floral resources for urban pollinators: A case of Geranium species. Urban Forestry \& Urban Greening, 32, 185-194. https://doi. org/10.1016/j.ufug.2018.03.018

Masierowska, M. L. (1993). The biology of blooming, nectar and pollen efficiency of 4 ornamental Ribes species. In VI International Symposium on Rubus and Ribes 352 (pp. 169-174). https://doi.org/10.17660/ ActaHortic.1993.352.23

Masierowska, M. (1995). Some ornamental shrubs as food source for pollinating insects. In Changes in Fauna of Wild Bees in Europe. (pp. 189-200) Bygdoszcz: Pedagogical University Press.

Matteson, K.C., Grace, J.B., \& Minor, E.S. (2013). Direct and indirect effects of land use on floral resources and flower-visiting insects across an urban landscape. Oikos, 122, 682-694. https://doi.org/10.1111/ j.1600-0706.2012.20229.x

Moquet, L., Mayer, C., Michez, D., Wathelet, B., Jacquemart, A. L. (2015). Early spring floral foraging resources for pollinators in wet heathlands in Belgium. Journal of Insect Conservation, 19(5), 837-848. https://doi.org/ 10.1007/s10841-015-9802-5

Muras, P. (2017). Standardy zakładania i pielęgnacji podstawowych rodzajów terenów zieleni w Krakowie na lata 2017-2030. Retrieved February 7, 2020 from https://dialogspoleczny.krakow.pl/wp-content/ uploads/2017/04/5_ANEKS_III_-STANDARDY_TZMuras-Poprawiony-01-02-2017.pdf

Neil, K., \& Wu, J. (2006). Effects of urbanization on plant flowering phenology: a review. Urban Ecosystems, 9(3), 243-257. https://doi.org/10.1007/ s11252-006-9354-2

Ostrowska, W. (1981). Obserwacje fenologiczne i pszczelarskie roślin nektaro- i pyłkodajnych w warunkach przyrodniczych Siejnika. In manuscript. 
Peters, K. A. (2012). Keeping bees in the city - disappearing bees and the explosion of urban agriculture inspire urbanites to keep honeybees: why city leaders should care and what they should do about it. Drake Journal of Agricultural Law, 17,597-644.

Pickett, S. T., Cadenasso, M. L., Grove, J. M., Boone, C. G., Groffman, P. M., Irwin, E., ... Pouyat, R. V. (2011). Urban ecological systems: Scientific foundations and a decade of progress. Journal of Environmental Management, 92(3), 331-362. https://doi.org/ doi:10.1016/j.jenvman.2010.08.022

Rutkowski, L. (2006). Klucz do oznaczania roślin naczyniowych Polski niżowej. Warsaw: PWN

Ruszkowski, A. (1998). Rośliny wskaźnikowe dla trzmieli (BombusLatr.) długo- i średniojęzyczkowych (Bombus Latr.). Pszczelnicze Zeszyty Naukowe, 1, 333-343.

Rysiak, A., \& Czarnecka, B. (2018). The urban heat island and the features of the flora in the Lublin City area, SE Poland. Acta Agrobotanica, 77(2). https:// doi.org/10.5586/aa.1736

Solga, M. J., Harmon, J. P., \& Ganguli, A. C. (2014). Timing is everything: an overview of phenological changes to plants and their pollinators. Natural Areas Journal, 34(2), 227-234. https://doi. org/10.3375/043.034.0213

Somme, L., Moquet, L., Quinet, M., Vanderplanck, M., Michez, D., Lognay, G., Jacquemart, A. L. (2016). Food in a row: urban trees offer valuable floral resources to pollinating insects. Urban Ecosystems, 19(3), 1149-1161. https://doi.org/ 10.1007/s11252-0160555-2
Szklanowska, K. (1992). Wydajność pyłkowa niektórych ozdobnych drzew i krzewów z rodziny różowatych (Rosaceae). Pszczelnicze Zeszyty Naukowe, 36,65-73.

Thomson, J. D. (1985). Pollination and seed set in Diervilla Ionicera (Caprifoliaceae): temporal patterns of flower and ovule deployment. American Journal of Botany, 72(5), 737-740. https://doi. org/10.1002/j.1537-2197.1985.tb08334.x

Thompson, J. D. (2001). How do visitation patterns vary among pollinators in relation to floral display and floral design in a generalist pollination system? Oecologia, 126(3), 386-394. https://doi.org/10.1007/ s004420000531

Warakomska, Z. (1972). Badania nad wydajnością pyłkową roślin. Pszczelnicze Zeszyty Naukowe, 16, 63-90.

Willmer, P. (2011). Pollination and floral ecology. Princeton University Press. 